\title{
Boundaries of the nation in the space of the urban: landscape and social memory in Istanbul
}

\author{
Amy Mills \\ Department of Geography, University of South Carolina
}

\begin{abstract}
Kuzguncuk, Istanbul, is known for its small-scale neighbourhood landscape and its close social ties, as well as its multiethnic history. The Armenian church and the mosque in Kuzguncuk have become symbolic 'evidence', in popular culture, of past multiethnic harmony. A Muslim elite is restoring Kuzguncuk's historic houses and its neighbourhood culture. The production of Kuzguncuk's landscape is sustained by two interrelated nostalgic narratives: a narrative of multicultural tolerance; and the narrative of the neighbourhood, the maballe, as the urban space of belonging and familiarity. However, the 'lie of the land' is that this landscape obscures a contentious and traumatic minority history, and gentrification is creating new social divides. Kuzguncuk's minorities are gone. The traumas they experienced during mid-century Turkification, as well as the current divisions of class and origin in Kuzguncuk, are denied in the popular narrative. This denial attempts to hide tension embedded in the national narrative of belonging. This study of the power dynamics shaping Kuzguncuk's landscape examines the terms of belonging, of being a 'Turk', in Turkey, a debate which both redraws and contests the boundaries of the nation in the space of the urban.
\end{abstract}

$\mathrm{K}$ uzguncuk is a small neighbourhood nestled in a valley on the Asian shores of the Bosphorus. While most neighbourhoods in Istanbul, a city of nearly 14 million, are crowded with multi-storey apartment buildings, Kuzguncuk's landscape is characterized by single-standing houses and small apartment buildings of a few floors. Kuzguncuk is surrounded by open green spaces, including two cemeteries, a restricted military zone and a park. A visitor can walk down Kuzguncuk's tree-lined main street to the boat station in about 10 minutes. Residents say, however, that it takes at least half an hour to exchange greetings with the neighbours they pass along the way, as the sidewalks are busy with people sitting in front of the coffeehouses or going about their daily errands in the local shops.

Kuzguncuk is known not only for its small-scale neighbourhood landscape and its close social ties but also for its multiethnic history. On the coastal road, an Armenian church and a mosque stand side by side (see Figure 1). Photographs and drawings of this church and mosque have so frequently circulated in print and 


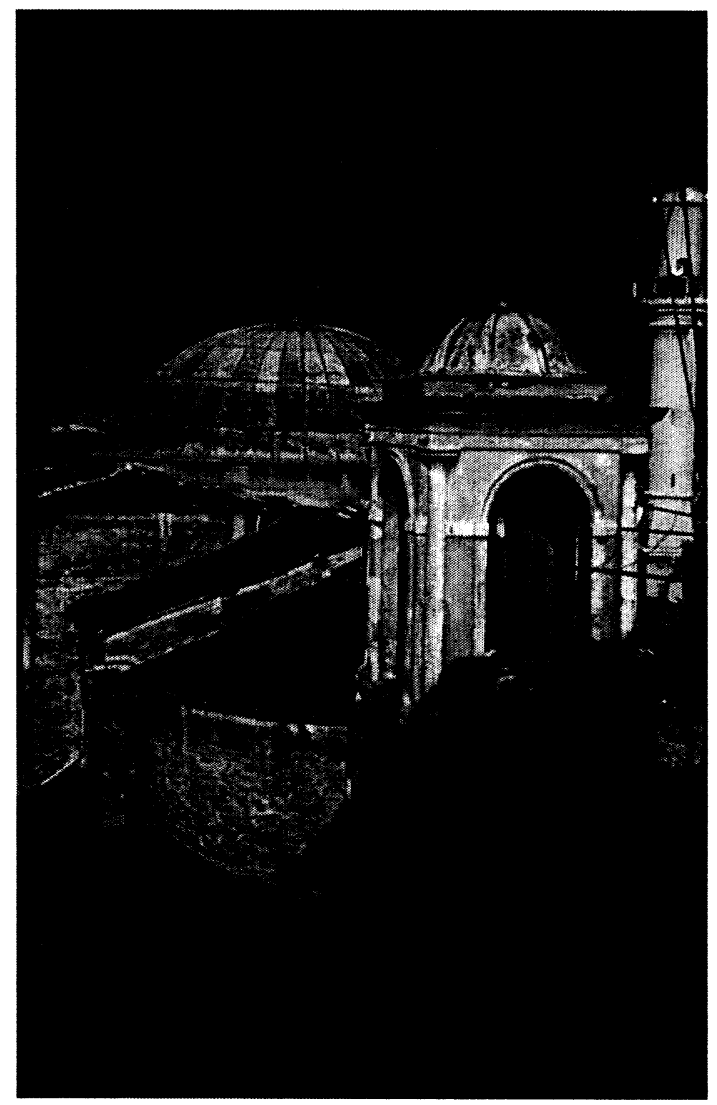

FIGURE 1 Surp Krikor Lusavoriç Armenian Orthodox Church and Kuzguncuk Mosque. This church was built in 1835 . Its congregation had decreased significantly by time the mosque next to it was built in 1953. It is frequently told in Kuzguncuk that the mosque gave the land to the church to be built, a gesture interpreted as a sign of exceptional intercommunal tolerance. This is untrue, however. Laws concerning the property of religious institutions would have prohibited such a gift, or even the purchase of this land by the mosque foundation. (This and all photographs were taken by the author.)

television media (alongside photographs of other churches and synagogues in the neighbourhood) that the image has become a symbol, serving as material 'evidence' of the social memory of past tolerance and harmony between a multiplicity of ethnic groups in the area (see Figure 2). These representations draw a new Muslim ${ }^{1}$ elite to Kuzguncuk to restore its historic houses and participate in its harmonious neighbourhood culture. Yet, while nostalgic images and narratives of the neighbourhood's past claim to retain historic, multicultural tolerance, the 'lie of the land' is that this landscape, and the narratives that create it, actually work to obscure a contentious and traumatic minority history. ${ }^{2}$ Furthermore, gentrification in Kuzguncuk is creating new rips in its social fabric. 


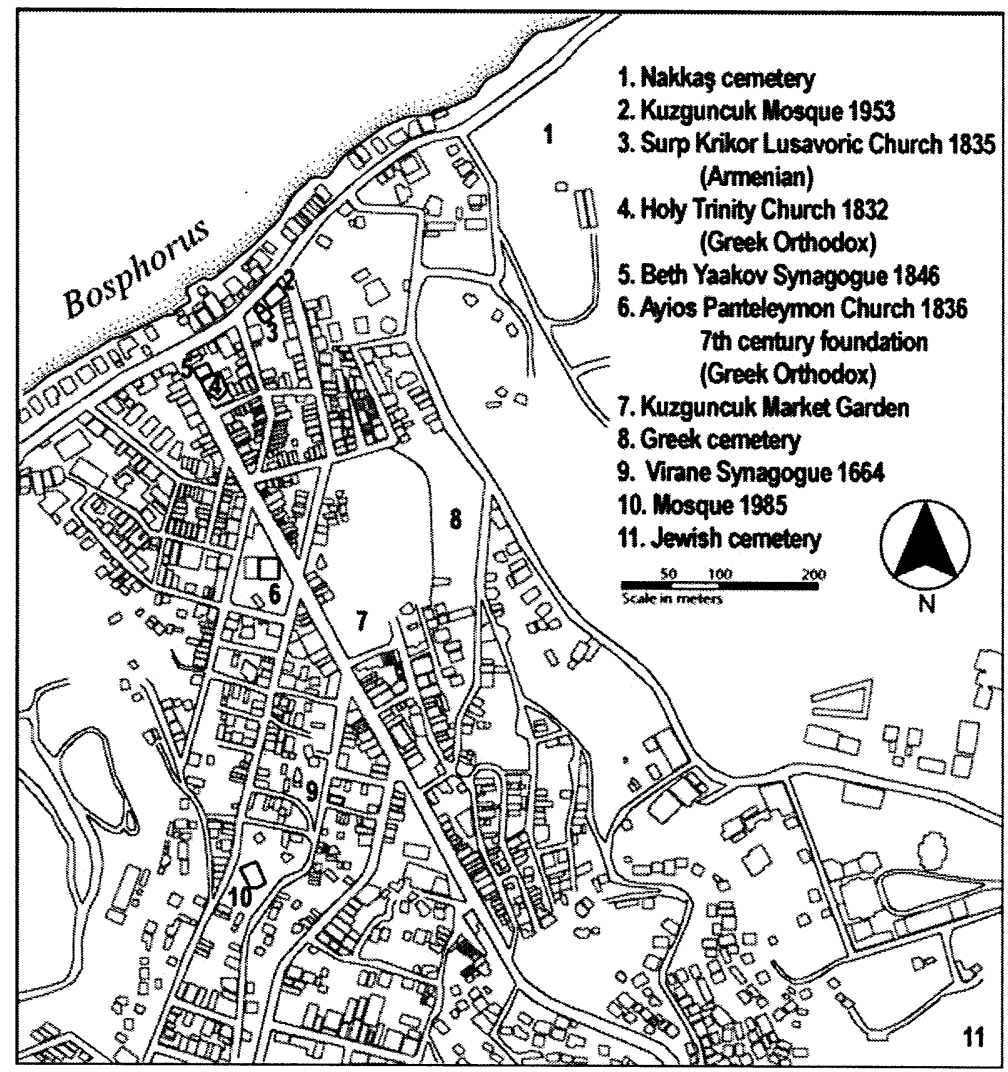

FIGURE 2 Religious Sites in Kuzguncuk. (This map and the map in Figure 3 were created by K. Maria D. Lane, Department of Geography, University of Texas at Austin.)

Although Kuzguncuk's landscape is known as 'historic', it is not a mere relic of the past but a landscape under continual and deliberate reproduction. This process is sustained by two interrelated nostalgic narratives: a narrative of multicultural tolerance; and the narrative of the neighbourhood, the maballe, as the urban space of belonging and familiarity. These two narratives themselves respond to and reproduce a social memory of a past cosmopolitanism. Kuzguncuk's minorities are gone, however, and the traumas they experienced during mid-century Turkification policies, as well as the current divisions of class and origin in Kuzguncuk, are denied in the popular narrative of harmonious neighbourhood life. ${ }^{3}$ This denial attempts to hide tension embedded in the national narrative of belonging, of being a 'Turk'. This study of the power dynamics shaping Kuzguncuk's landscape, then, is a study of the issues at the core of the cultural debate in Turkey today concerning what it means to be a member of the Turkish nation.

I begin the paper, first, with an explanation of my research methodologies and the theoretical frameworks concerning landscape and memory that structure my analysis. 
The paper then brings questions concerning nostalgia and landscape to the Turkish context. I discuss nationalism in Turkey, and outline a historic geography of Istanbul with attention to the mahalle as the space of daily life. I conclude this section with an examination of how minority identity is produced by (and sustains) both nationalism as a feeling of belonging in the nation and the mahalle as the space of belonging in the city. The paper continues by retracing these themes in the case of Kuzguncuk. I examine how ideas of belonging in the mahalle are produced in larger popular culture, resulting in the creation of a nostalgic cultural landscape in Kuzguncuk. I then present two sets of oral histories from Kuzguncuk. The first concerns the history of a market garden which once belonged to a Greek family and which is, today, the subject of green activism on the part of the Kuzguncuk Neighbourhood Association. The second cluster of stories narrates the 1955 anti-Greek riots in Istanbul as they are remembered (and un-remembered) in Kuzguncuk. My conclusion interprets the nostalgia for Istanbul's minorities. I situate it within the context of a cultural debate concerning the terms of belonging, of being a 'Turk', in Turkey, a debate which both redraws and contests the boundaries of the nation in the space of the urban.

\section{Methodology}

At an early stage of my research, I observed a popularity for objects and places that evoked nostalgia for 'old Istanbul', especially for things related to the historic culture of the mahalle. I also frequently heard a nostalgic narrative of Kuzguncuk's special mahalle landscape and culture (in the words of one Istanbul resident, 'Well, if you're interested in mahalles, you should go to Kuzguncuk, that's a real mahalle!') I aimed to compare individual oral histories and observations of daily life to these popular discourses. I focused on the landscape because it was essential both to how people described Kuzguncuk and to representations of the mahalle in popular culture.

The narratives analysed in this paper were gathered in Istanbul while I lived there nearly continuously for two years between June 2001 and August 2003. I lived in Kuzguncuk for 17 months between October 2001 and March 2003, and conducted participant observation with representatives of the three most dominant groups involved in the contemporary landscape so frequently represented in nostalgic discourse: the Kuzguncuk Neighbourhood Association (Kuzguncuklular Derneği); a group of primarily middle-class Black Sea-origin families; and a group of lower middleclass Jewish and Jewish-intermarried families. I participated in the traditional practices of women and met with them in their homes at their invitation. ${ }^{4}$ These sustained relationships facilitated my meeting many other people who also visited these spaces. I met a diversity of people: recent migrants and Kuzguncuk-born Muslim families of diverse socioeconomic backgrounds, and Jewish, Greek and Armenian people (a few live in Kuzguncuk but most of these informants were of Kuzguncuk-origin families who live in other parts of Istanbul). I also met academics, architects, urban planners and activists involved in urban issues. 


\section{Landscape, memory and nationalist discourse}

Neither the landscape of Kuzguncuk nor the social memory reproduced through it are innocent. Rather, they exist in a complex relationship to a nationalist discourse that inscribes the boundaries of belonging to and being excluded from the nation: of who is a Turk, and who is 'minority' (azlnlık). ${ }^{5}$ The oral histories I gathered from minority residents challenge the dominant social memory of harmony and belonging, exposing both the role of the state and of inequal daily social relations in constructing the categories of 'Turk' and 'minority'. Revealing the constructed nature of these categories is important because landscapes, in their materiality, have the power to make this discourse appear natural and uncontested. ${ }^{6}$ In spite of the power of nationalist discourse, however, social memory and the creation of a 'mahalle landscape' in Kuzguncuk do not necessarily indicate that the memories of ordinary people are appropriated by elites and pressed into the service of conquest and domination' ${ }^{7}$ Not all residents of Kuzguncuk (or of Istanbul) share the social memory of the past, ${ }^{8}$ though the urban Istanbullu cultural discourse has become so pervasive that all narratives of the city work through and alongside this narrative, even those that contest it.

One element at the core of social memory in Kuzguncuk is a notion of the urban as anti-rural. ${ }^{9}$ Kuzguncuk's social memory employs a nostalgia for familiar community life, referring to the time before Istanbul's older urban fabric and open green spaces were replaced with apartment buildings to house new migrants. Other neighbourhoods of Istanbul (including the Bosphorus districts of Çengelköy, Beylerbeyi and Arnavutköy, and other parts of the city known for minority history like Fener, Samatya and most especially Beyoğlu) also locate nostalgia for the lost Istanbullus, the Greeks, Jews and Armenians who took the character of the city with them when they departed. ${ }^{10}$ The nostalgia both for Istanbul's minorities and for the small-scale historic urban landscape inform the social memory in Kuzguncuk, making it an exceptionally good site for examining the complex relationship between social memory, landscape and identity in Istanbul.

David Lowenthal writes that both nostalgia and heritage rely on interpretations of history to compensate for a present malaise, for a lack of community and a need for identity in place. ${ }^{11}$ The social memory in Kuzguncuk can thus be read as a narrative of the past which attempts to cope with the present and articulate an imagination for the future. ${ }^{12}$ It thus responds to political and cultural tensions in the city that expose the fault lines in the nationalist narrative of secularism and modernity, and of Turkey as an ethnically 'Turkish' nation. Nostalgia for Istanbul's minorities subtly undermines a fundamental element of Turkish nationalism - that Turkey is an ethnically Turkish territory - by raising an oblique question regarding the role of the state in the departure of these communities from Istanbul. Furthermore, the nationalist definition of Turkey as a secular nation is destabilized by the increasing presence of political Islam in Istanbul. The issues of ethnicity and nationalism, as well as of rural origin and urban life, have come to a heightened tension in the last fifteen years, because Istanbul's new migrants are predominantly Kurdish. ${ }^{13}$ As Istanbul's population becomes increasingly of rural 
origin, issues of dress, language, and cultural practice challenge notions of who can claim to be 'of Istanbul', or the bearer of an 'Istanbul culture'.

The cosmopolitan social memory is sited in the space of the mahalle because of its historic and contemporary sociospatial function as the residential space of the city. The mahalle was a space which grouped ethnic communities and was also produced through the interactions of cosmopolitan daily social life. The following discussion of the history of the mahalle will clarify the link between the two threads of social memory concerning close community relationships and multiethnic tolerance, and reveal the ways in which this urban space was transformed by Turkish nationalist discourse.

\section{Social and spatial boundaries of the mahalle}

The Turkish word for 'neighbourhood' is maballe. While the mahalle is the urban residential space, the word also refers to a space of social memory in Turkish popular culture defined by familiarity, belonging and tolerance in a local place. The social memory relies, in part, on the complex social history of the mahalle in Istanbul and in other cities of the former Ottoman empire (in Arabic, maballa). Historically, the mahalle spatialized ethnic or religious identity on a local scale, reflecting the administrative structure of the Ottoman millet system. ${ }^{14}$ This system was created by the Tanzimat reforms of the nineteenth century which made Ottoman subjects equal under the law, regardless of religion or language. ${ }^{15}$ This system gave non-Muslim religious and ethnic groups semi-autonomous governance within a hierarchical structure that made a religious leader responsible for each millet. Each mahalle was governed by a local religious leader, making the mahalle a socio-spatial locator for the ethnic and religious identity of a particular community. Individual identity also depended on locality in the mahalle: ${ }^{16}$ legal documents in Istanbul identified individuals by mahalle of residence before the creation of surnames. ${ }^{17}$

While mahalles had place identities related to their ethno-religious communities, they were not always homogeneous. ${ }^{18}$ Furthermore, the boundaries of mahalles in Istanbul were unmapped and subject to interpretation. ${ }^{19}$ Yet the mahalle had a cohesive identity fundamental to how Ottoman residents located themselves in the urban social milieu. Residents formed a collectivity through ties of mutual responsibility, in the collective collection of taxes, for example, and in the enforcement of social norms. ${ }^{20}$ The spatiality of the mahalle was thus defined by social practice rather than a bounded, physical or a mapped, administrative geography.

Mahalle culture inherited the cosmopolitanism of Istanbul. Istanbul residents possessed fluency in a variety of languages and cultures, and daily life functioned through a mutual recognition of difference. Sami Zubaida describes this cosmopolitanism:

Groups of different religious and ethnic backgrounds intermingled and exchanged ideas and lifestyles... No definite and rigid boundaries had been drawn and the state did not yet exert its power of standardization or impose its norms on its citizens. ${ }^{21}$ 
Yet, if 'no definite and rigid boundaries had been drawn' in the time of empire, during the early years of the Turkish Republic and in the era between the 1940s and 1960s, firm boundaries of ethnic identity as 'Turk' and minority were created. Former millet communities became minorities, azınlık, marking a social distinction that eventually undermined the historically cosmopolitan character of the mahalle. The boundaries of the nation began to be negotiated through the space of the urban, in part through the 'Turkification' of the mahalle.

\section{Boundaries of the nation in the space of the urban}

Zygmunt Bauman, relying on the work of Frederick Barth, links ethnicity to the problem of national identity. The nation created an 'ethnic category' to legitimize its own existence by marking the terms of exclusion and thus making the nation the preferable category of identity. ${ }^{22}$ For Turkey, the category of 'minority' inscribed a boundary of exclusion, making the imagined community of the Turkish nation the space of belonging. ${ }^{23}$ In the early Republican period, 'minority' meant the former 'millet' communities of the Ottoman Empire. ${ }^{24}$ Millets had an ethnic-religious definition, and many had relationships of privilege with European powers. By defining the minority, Turkey defined a national boundary to legitimize the new Turkish state. If these boundaries defined who had claim to place in the nation, in the same way the boundaries of insider/outsider in the mahalle defined belonging in the space of daily urban life. The conceptual boundaries of the new nation relied on territorial and cultural location in provincial Turkey, and it responded to threats from Europe by identifying itself as modern and secular, like powerful European nations.

In the beginning of the twentieth century, as the Ottoman empire lost territory and was under threat, Turkish nationalism emerged in the person of Mustafa Kemal Atatürk. ${ }^{25}$ Atatürk's ideas synthesized some elements of Turkey's Ottoman heritage with European-style modernization viewed as necessary for Turkey to survive among European nations. He supported a reformist agenda, identifying it with the idea of a strong Turkish nation, and proposed replacing a traditional civilization with a modern European one. ${ }^{26}$ In spite of his emphasis on secularism, he defined Turkey as a Muslim nation, because Islam was considered an integral part of Turkish culture. The other integral part of Turkish culture was Turkish ethnicity, which identified Turkey's roots in an ethnically Turkish past and in the migration of Turkish tribes from Central Asia across Anatolia.

These two elements of nationalism in Turkey combined in the idea of the 'Turk', that is, the ideal member of the nation who was Muslim and ethnically Turkish. This formed a national exclusion of the many religious, ethnic and linguistic minorities in Turkey, creating an identity crisis that continues to undermine a cohesive nationalism in Turkey today. Recently, a movement has emerged which argues for using the word Türkiyelimeaning 'of Turkey' - instead of the word Türk when referring to people who live within the territorial boundaries of Turkey. This word acknowledges and includes nonethnically Turkish people as well as non-Muslims within the nation, and itself has 
become a subject of debate. ${ }^{27}$ The problem of national identity and the categories 'Turk' and 'minority', then, is as visible in the everyday speech of Istanbul as it is in the cultural landscape.

The emerging new Turkish nation demanded an ethnic and territorial integrity. The state engaged in military, economic and political aggression to create a nation-state in conformity with a Turkish, Muslim nationality. In the early decades of the twentieth century, wars in the Balkans, the massacre and emigration of Armenians in 1915 and the 1923 population exchange with Greece succeeded in removing most of Turkey's minority populations. Istanbul, the former capital of the empire, was a remnant of the imperial, Ottoman past. Although some early policies enacted in Istanbul targeted economies and cultures of minorities (e.g. banning non-Turkish languages, and closure of certain types of minority-dominated sectors of employment to minorities), it was not until mid-century that anti-minority policies were employed to 'Turkify' the city. The following discussion situates Kuzguncuk within this larger history as a multiethnic mahalle, as several ethnic and religious groups lived there over time. I then describe how nationalist policies changed the social and cultural character of urban life in Istanbul, and in Kuzguncuk, relying on information gathered through participant observation and oral histories.

\section{Population shifts in the city and in Kuzguncuk}

Kuzguncuk was a Bosphorus village until it became a mahalle of Istanbul after the city expanded from the historic peninsula around the turn of the twentieth century (see Figure 3). Its earliest Greek Orthodox church dates back to at least the eighth century; and Greek Orthodox people migrated to Kuzguncuk from central Anatolia to rebuild this church and to build a second one in 1832. Jews of Kuzguncuk descend from Sephardic Spanish migrants who arrived after 1492. Kuzguncuk has two synagogues and a large Jewish cemetery with graves from the early sixteenth century. Kuzguncuk's Armenian population of artisans and workers arrived later, and built the Armenian church in 1835.

Kuzguncuk's Muslim population was very small, composed of a few elite families who lived in waterfront mansions and on the hills overlooking the Bosphorus, until rural migrants began to arrive in the early 1940s. These Muslims from the Black Sea region of Turkey moved into Kuzguncuk's historic core and eventually owned the shops on the main street. They completed the Kuzguncuk mosque in 1953. By the time this mosque was built, Kuzguncuk's Armenian community had almost completely disappeared. Migrants continued to arrive through the 1960s and 1970s and built squatter settlements on Kuzguncuk's periphery. As in other parts of the Istanbul, after the 1942 anti-minority Property Tax, the 1955 anti-Greek riots, and especially after the 1964 deportation of Greeks, Kuzguncuk's minorities dwindled to very few. By the early 1970s most remaining families had moved to other parts of Istanbul, to recongregate in new neighbourhoods with other minorities. Today there are approximately 10 Jewish households (they are intermarried to non-Jews, however) and a few Greek or other 


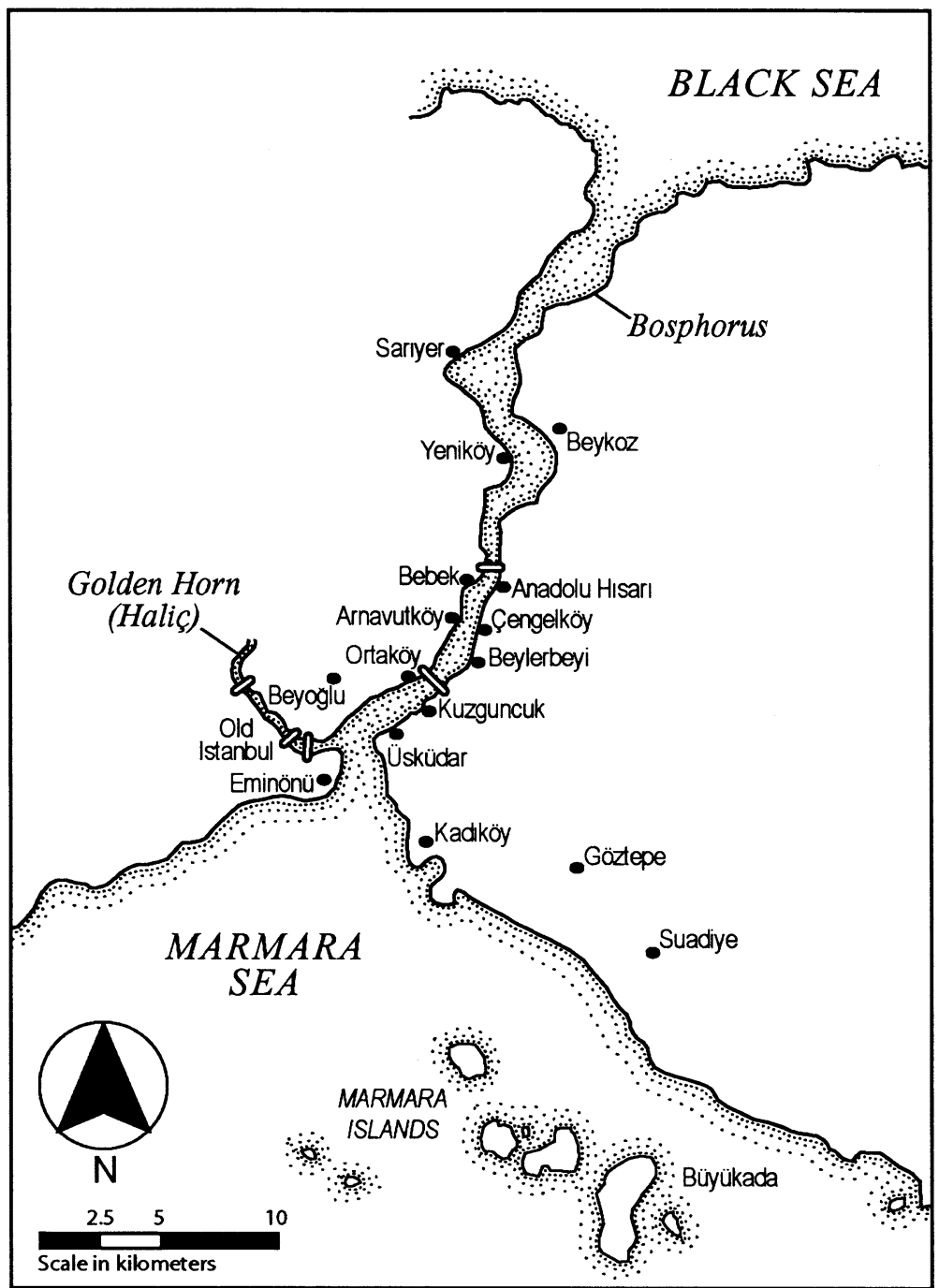

FIGURE 3 Istanbul neighbourhoods. (This image is reproduced in Amy Mills, 'Reading narratives in city landscapes: nationalism, minority history, and cultural identity in Istanbul', Geographical review 95(3), special issue: 'Geographical dimensions of the New Middle East.')

Orthodox families connected to the Greek Orthodox church (some of these families are intermarried too). ${ }^{28}$ There are a few elderly Armenian, Greek and Jewish residents.

The result of Turkification ${ }^{29}$ was that, by the late twentieth century, Istanbul's cosmopolitan culture had disappeared with the emigration of its non-Muslim minorities. In this way the hegemonic processes that define and create the nation as ethnically Turkish and Muslim were shaping city landscapes. Many minority properties in the city were sold or confiscated between the 1940s and the 1960s, when the city 
witnessed the first very large wave of twentieth-century rural-urban migration. Between 1945 and 1975 Istanbul's population increased from one to four million. ${ }^{30}$ In spite of these tumultuous population shifts which fractured urban communities, it is this very period which is nostalgically narrated in the dominant collective memory as one of tolerance, brotherhood and belonging in the mahalle.

Other sociocultural changes have affected social life in the mahalle. Residents say that when more families began to own televisions, fewer people visited each other outside in the evenings, and the open cinema in Kuzguncuk closed down. Kuzguncuk once had many small family-owned corner groceries, but today most shopping is done in two larger supermarkets. Traditionally, the practices of neighbouring (komşuluk) and expressions of knowing (tanımak) which created networks of support between neighbours and in resident-owned shops and businesses, defined the mahalle ${ }^{31}$ and made it the space of familiarity and belonging. ${ }^{32}$ Yet by the 1980 s these practices, and the collectivity of social life in the mahalle, had nearly faded away. Today, overurbanization and the increasing polarization of wealth create new and alienating landscapes, ${ }^{33}$ and Istanbul residents lament the loss of the city's character. As the social practices that characterized traditional mahalle life were eroded, the mahalle as a Turkish, urban cultural space moved into the realm of social memory as the embodiment of familiarity in place. Historic mahalles in Istanbul become symbols that signify this social memory, while, paradoxically, the social fragmentation in their landscapes manifests the tensions underlying recent cultural change in the city.

\section{Kuzguncuk and the nostalgic narrative}

Long-term media attention to Kuzguncuk has made it a favourite place through which to display the 'authenticity' of mahalle life. Newspaper articles and television programs single out Kuzguncuk for its ideal historic landscape and integrated life.

\footnotetext{
The mansions protected until today, the historic boat station and the people tightly bound by neighbourly relationships, make Kuzguncuk possibly the most beautiful neighbourhood on the Bosphorus. The work there to protect the old structures is done with the aim of creating a new way of life. More than protecting the old structures, is the true desire to protect the relationships, the love and understanding between people. Kuzguncuk people are making decisions for themselves, trying to prevent Kuzguncuk from becoming foreign. ${ }^{34}$
}

These representations of Kuzguncuk are part of a larger phenomenon: the cultural production of a social memory of mahalle life.

The social memory of mahalle life is produced through print media, television shows, comic strips and websites that bring historic Istanbul landscapes to life in the imagination. The reissuing of older popular literature contributes to reviving and reproducing the mahalle in social memory (for example, Sait Faik's Maballe coffeebouse, a collection of short stories set in 1940s Istanbul, was reissued in $2002^{35}$ ). Many popular and academic magazines in Istanbul have published articles and photo essays on historic mahalles in recent years. The mahalle is present in advertising, as well, which relies on the desire for the familiarity of mahalle life to sell products. In 2002 , the 
international HSBC company, in line with its template of 'localizing' its services, produced a television commercial that used the mahalle to target Turkish consumers by employing a common familiarity with local custom. In the commercial a young boy uses a hand-held camera to make a video to introduce us, the viewers, to his mahalle. 'This is our mahalle', he says. We see the streets of upper-class Nişantaş1 (another old minority neighbourhood) and its old, European-style apartment buildings. $\mathrm{He}$ introduces us to one of the old neighbours, who recognize him as a local mahalle kid. He shows us the mahalle corner store. Then he says, 'This is our bank', and the ad focuses in on HSBC.

Another commercial (also aired in 2002) which utilized the social memory of the mahalle to create a name-brand image signifying familiarity and community was produced by Aria, a Turkish telecom firm. The logo for this advertisement was 'Communication is an art' ('Iletişim sanattir'). The viewer watches a handsome, young male artist painting a large scene of Beyoğlu (another historic minority area). The artist listens to an old man talking about the good old days, and the theme of his words is communication. Old-fashioned music plays as the old man says, 'In our days, there were nice conversations, there was wonderful neighbourliness ... where has it gone, where has it gone?' The young man nods and smiles in understanding. The point of the commercial is that Aria, with its art of communication, can restore good relationships in today's city like in the past. The increasing popularity of images and text representing the mahalle both rely on and contribute to the production of a social memory with a corresponding landscape.

Throughout my research I was curious about the relationship between the social memory of mahalle life in Istanbul and the complex reality of daily life. Many residents told me, 'In the old days, we were all like siblings, ${ }^{36}$ we all celebrated each other's holidays, and religion made no difference. Even today Kuzguncuk hasn't lost its mahalle character like the rest of Istanbul.' Residents referred to mid-century Kuzguncuk as 'Little Paris', and reminisced about their old minority neighbours by name. The names most frequently mentioned were those of the men who ran the businesses along Kuzguncuk's main street, such as Ilya the Greek market gardener, and Serkiz, the Armenian man who had a sweets shop near the boat station. The narrative's theme of multicultural harmony and close neighbourly relations denied not only the tensions I observed in the neighbourhood's current social segregation (mostly of class, but also of origin and of secularism/religiosity) ${ }^{37}$ but also the near total disappearance of its minority communities.

Uryanizade Street is the most developed street of historic preservation in Kuzguncuk (Figure 4). The project was started in 1978 by an architect called Cengiz Bektaş, who restored the houses with the aim of resurrecting the 'tolerance and harmony' characteristic of Kuzguncuk. ${ }^{38}$ For Bektaş, Kuzguncuk's landscape symbolized the beauty of Istanbul's past cosmopolitanism. In his book titled 'The Other Name for Tolerance: Kuzguncuk', he draws an illustration of the Armenian church and the mosque which stand next to each other, and asks, 'Don't the domes of the mosque and church mixing together illustrate to people the very meaning of tolerance?'39 Bektaş was so successful in restoring houses on Uryanizade Street that the neighbourhood's 


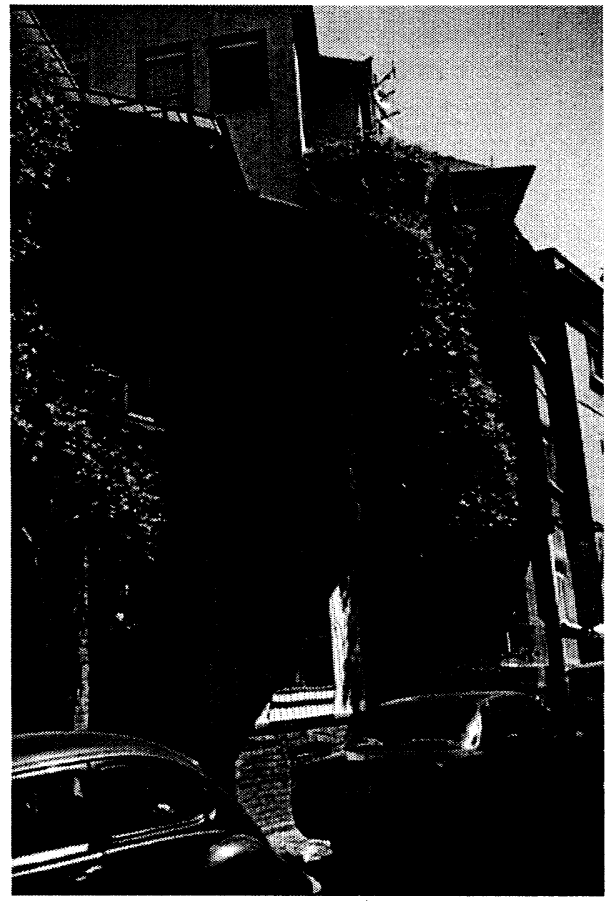

FIGURE 4 Uryanizade Street

landscape was chosen for the setting of the most popular Turkish television show in history, Periban Abla, which emphasized the closeness of relations on the main street and between the beautiful houses on Uryanizade. The program's success ushered in a new genre of television shows in Turkey, all based on nostalgic representations of mahalle life. ${ }^{40}$ In 2003 two new mahalle television serials were filmed in Kuzguncuk, including Ekmek Teknesi (Bread Boat). However, this most recent stage in the creation of mahalle landscape forms reached the absurd when the film crew of this mahalle show rented a kebab restaurant and redecorated its façade to look like an old-fashioned bread bakery. Although there are two old bread bakeries in Kuzguncuk, the film set necessitated a more 'authentic' bakery than the ones that exist in reality (Figure 5).

Media representations increased Kuzguncuk's popularity in the 1990s, and the real estate market boomed. ${ }^{41}$ These later gentrifiers, however, were more concerned with producing a historic-looking form than renovating an old structure; wooden houses were razed to the ground and rebuilt in cement with fake wooden façades in bright colours. Throughout the 1990s and early twenty-first century, magazine and newspaper articles, photo essays and local television programmes popularized Kuzguncuk's mahalle landscape for its retention of its historic cosmopolitanism, in spite of the fact that very few minorities remained. ${ }^{42}$ These representations worked to create more mahalle landscapes in the neighbourhood and in other parts of the city through gentrification. 


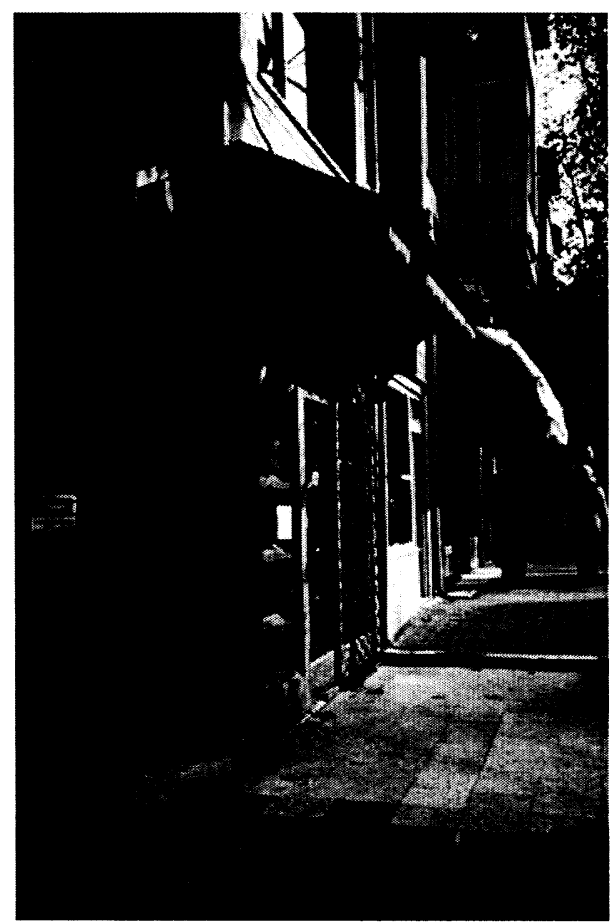

FIGURE 5 Ekmek Teknesi

Even as Cengiz Bektaş writes of the extended family of Kuzguncuk, the very movement he began created a new social divide. As Kuzguncuk came increasingly to symbolize the collective memory mahalle of close relations and tolerance, neighbourhood relations split even further. ${ }^{43}$ The mahalle on the ground becomes more fragmented, divided, more like the conflicted postmodern city of Istanbul, as the mahalle in the imagination becomes more popular, more synthetic, more seamlessly perfect. The narrative of peace and tolerance embedded in the landscape of social memory obscures other, untold stories of the mahalle's past: the traumatic events that pushed out the minority communities.

Don Mitchell argues that 'one of the purposes of landscape is to make a scene appear unworked, to make it appear fully natural. So a landscape is both a work and an erasure of work. It is therefore a social relation of labor, even as it is something that is labored over. ${ }^{, 44}$ In spite of its recent creation, the Kuzguncuk landscape appears as the 'historic' and therefore natural theatre of mahalle life signified by the social memory, making the narrative appear to be true, or real. The memory requires its symbols to give it authenticity, producing its landscape even while it erases the minority family history embedded in the wooden houses and the main street shops. The connection between landscape creation and representation is thus politicized. The next section will present two sets of competing narratives which provide the thread for the 'evidence' of close, cosmopolitan mahalle life and the untold stories of place which expose its falsity. The 
narratives centre on two places: the Kuzguncuk market garden, a garden formerly owned and run by a Greek family, and Icadiye Street, the main street of Kuzguncuk, which was the setting for violent anti-minority riots in 1955.

\section{Kuzguncuk: claims to place}

\section{The Kuzguncuk market garden: contesting narratives in place}

My first contacts in Kuzguncuk were with members of the Kuzguncuk Neighbourhood Association. When I arrived in 2001 the association was conducting a heated media campaign and legal struggle to prevent the development of the historic market garden (bostan), in the heart of their neighbourhood. Most association members were related either to the Black Sea-origin migrants or to newer, wealthier gentrifiers. The association had been fighting development of the garden for several years, but their activity increased as the civil society organization movement boomed in Istanbul after the earthquake in August of 1999. The association was working hard in 2001 before the renewal of the 10-year lease came up in 2002, hoping to take the renewal period as an opportunity with which to assert their own vision of Kuzguncuk as a green historic neighbourhood. The following section relates the discourse surrounding this project to the narrative of the last descendant of the Greek family that owned the garden. My aim is to illustrate the role of the past in place narratives which involve claims of belonging through the assertion of ethnic and cultural identities.

The historic market garden in question was owned for generations by a Greek family. Oral histories of Kuzguncuk often mention the garden and Ilya, its owner and gardener. By 2001 the property had an ambiguous status and lay untended for years while it was rented on a decade-long lease. The renter was a politically connected and wealthy man called Mehmet Haberal, who at various times proposed building a kidney dialysis hospital and a private school on the site. The neighbourhood association gathered hundreds of signatures of support, held a media campaign and hired lawyers to interpret city planning and historic protection codes. The lawyers filed a suit after they determined that building on the site was illegal from several points of view. The association failed to obtain a binding, legal ruling on the case, although they were victorious in pushing out the developer and acquiring a new renter who has agreed to use the space for 'green' purposes. In the widespread media coverage of the issue, the garden became a symbol of a much larger threat to the city:

\footnotetext{
Now, inside this treasure chest, in our days, Ilya's garden which is as valuable as gold with all its characteristics, will shortly be claimed with screams of panic that nothing will remain anywhere. Furthermore, the places we claim, the places we are afraid of losing, with our values, our culture, with the loss of our memories ... Ilya's bostan has become a symbol of all of this. ${ }^{45}$
}

For the neighbourhood association, the garden represented what was most threatened by urban growth and government corruption in Istanbul. Their movement passionately articulated a claim to place, staking territory for a greener vision of the future. 
The minority history of the garden gave it a heritage to be invoked in romantic descriptions of it as Kuzguncuk's 'treasure'. Several members of the neighbourhood association told me about Ilya and his garden. Some remembered sneaking into his garden to steal fruits as children. They remembered long-term relations with him as frequent local customers. Ilya's identity as Greek was always mentioned in stories about the garden. The website of the association also told Ilya's story. ${ }^{46}$ In conversations with association members, and in newspaper articles about the garden (most of which rely heavily on interviews with residents), the Greek history is what makes it a heritage place for Kuzguncuk, although the garden's importance as a green space is the most immediate activist issue. It may be, as a few members of the association told me, that the association has shied away from focusing too explicitly on this history for fear that remaining family members would file a lawsuit and succeed in reclaiming this property from the state, in which case the association would lose any chance of being able to control its future development.

Paradoxically, it is the market garden's minority history that made it open to illegal development in the first place. When minority properties became properties of the state they then became vulnerable to local corruption. In 2002, Behice Özden published an article in Radikal newspaper about the Kuzguncuk market garden's legal history, citing its property deed and revealing that its confiscation by the Turkish Ministry of Foundations was illegal. ${ }^{47}$ The deed cites a law concerning the abandonment of minority property, enacted in reference to properties 'abandoned' by Armenians after the 1915 massacre in Anatolia. The market garden had never been abandoned, however: the gardener who owned it worked the garden until his death, and was buried in the Greek cemetery that adjoins the garden. At this point his share in the property was not passed to his descendant but became the property of the state.

Many properties in Istanbul owned by the Turkish state - by the Ministry of Foundations or by the Treasury - were minority properties which came to the state through abandonment (a result of deportation or emigration) or worse, through alleged illegal confiscation. ${ }^{48}$ The practice of confiscating Greek properties dates back to 1964 , when the Inönü government revoked a 1930 treaty granting Greek citizens permanent residency in Istanbul. These people were born in Istanbul but held Greek passports because their ancestors had come from provinces of the Ottoman empire that were eventually incorporated into Greece. ${ }^{49}$ Nine thousand people were legally affected, ${ }^{50}$ but thousands more related to them by marriage also emigrated. The emigrants were only permitted to take 20 kilos of possessions and $\$ 22$, and were prevented from selling their property. Much of their property was confiscated by the Turkish state. ${ }^{51}$ This event was the most significant of all the 'Turkification' policies in Istanbul in terms of how it caused a significant population shift in Kuzguncuk. Although all mahalle population and property records were closed to my research, stories I gathered tell that many houses in Kuzguncuk stood empty after this time. They were subsequently occupied or purchased by incoming Black Sea migrants, marking the most significant shift in the population and culture of the neighbourhood. The confiscation of the Kuzguncuk market garden by the Turkish Ministry of Foundations should be understood within this larger sociopolitical context. 
In the early spring of 2002 , the neighbourhood association learned that the renter had abandoned his development projects for the market garden and given up his lease. The association members were jubilant. I was happy upon hearing their news, too: any small victory to save a green space was to be celebrated. On that very day, by coincidence, a friend brought me to meet Dimitria Teyze ${ }^{52}$ (Aunt Dimitria), a last descendant of the extended family that owned the market garden. The difference between her relationship to the garden and that of the Kuzguncuk residents that fought to protect it resonated throughout my entire project. Encountering Dimitria Teyze was disturbing and exhilarating because she lives deeply in the very past I had heard so much about. Her narrative of Kuzguncuk's history is not one of tolerance, however, but of rage and sorrow.

In a 'history of Kuzguncuk' she wrote for me, Dimitria Teyze explained that 'Turkey's laws transferred Greek property to Turkish hands, and with their leaving and forced migration, Kuzguncuk Greek properties were lost in various ways'. Her story about Greeks in Kuzguncuk not only speaks to the larger history of the city, but is fundamental for her own personal identity. I asked her to draw a mental map of Kuzguncuk, and on the space representing the market garden she wrote, 'the green garden belongs to the [her family name] family'. By inscribing her family name on the map, Dimitria claimed the neighbourhood's history as personal and individual. Her story is one of thousands rarely heard ${ }^{53}$ that provide an essential clue to the nature of the recent transformation of Istanbul's cultural landscapes. Her words challenge the prevailing narratives of city history and of Kuzguncuk, revealing the authenticity of this mahalle to be 'a hugely mystified, ideological project that seeks to erase the very facts of its (quite social) production'. ${ }^{54}$

\section{Icadiye Street: social memory and remembering violence}

The period from the 1940s to the 1960s was a painful one for the minority residents of Istanbul. In 1942 the state enacted a wartime property tax which was levied in arbitrary ways, and to a disproportionately high level on Istanbul's minorities. ${ }^{55}$ of all Istanbul properties sold to pay the tax, 97 percent were sold by minorities. Although Muslims who couldn't pay the tax were not prosecuted, 12000 Jews who could not pay were sent to work camps. The property tax inscribed the boundaries of the nation on the cultural landscape of Istanbul, territorializing a Turkish national identity in this city known for its multiethnic character. In the words of Turkish historian Ayhan Aktar, 'Many famous places in the district of Beyoğlu which were important to Istanbul's cultural and social map ... changed hands in a moment with the aim of paying the property tax'.56 Articles in local newspapers at the time referred to 'nationalizing' and 'Turkifying' Beyoğlu. ${ }^{57}$ Most of the properties sold were purchased by private Muslims, but 30 percent went to the Turkish state, including the Istanbul municipality. Jews in Istanbul cite the property tax as a primary reason for the massive emigration of 30000 Turkish Jews when the State of Israel was declared in 1948. Although Kuzguncuk was never a very wealthy 
neighbourhood, residents there felt the social and emotional impact of the tax. One resident described a painful memory of the police coming to a neighbour's house to confiscate the family's property, dumping candy onto a table in order to steal the silver candy dish. Several of Kuzguncuk's older residents remember the departure of Jewish neighbours after this time.

Istanbul's minorities were again targeted in 1955 when local Greeks became pawns in the Cyprus conflict between Turkey and Greece. On the night of 6-7 September 1955 several riots swept Istanbul, destroying thousands of Greek owned-properties. Rioters looted shops, emptying their goods onto the street. Nearly 80 churches were burned. The incident was provoked by false reports that Atatürk's birthplace in Salonica had been bombed. Although initial reports placed the blame on 'mobs' and 'communists', the riots were soon revealed as a planned state retaliation to events in Greece. The massive destruction created a climate of fear that spurred more minority emigration. This event was the beginning of the near total exodus of the historic Greek community from Istanbul. ${ }^{58}$ It is popularly claimed that this event did not take place in Kuzguncuk, although Kuzguncuk's church was burned, and some residents told me stories of looting and a night of mobs running up the main street shouting, 'Death to the heathens!'.

Stories of the riots of 1955 , which are referred to as 'the 6-7 September events', betray the contradictions embedded in the nostalgic social memory of Kuzguncuk. The narratives of this event related below were chosen because they reveal the ways in which the social memory is constructed through and alongside discourses of both nationalism and what constitutes the urban. The 6-7 September events are significant because, although they were a state-organized act of violence, they relied on already existing prejudices for their implementation. This reality of social prejudice, which led to a night of exceptional violence, underlies all narratives of the riots, which is precisely why stories of Kuzguncuk's past are conflicted on this topic. The interviews that touch on the riots are important because the riots are popularly denied in Kuzguncuk, and memory of them remains largely unspoken. This (un-)remembering is significant because the event of the riots undermines the equality and tolerance between Muslims and non-Muslims so valuable to the social memory. The events reveal the categories of 'Turk' and 'minority' to be constructed (through action or policy), not natural (pre-existing), exposing the presence of these nation-boundaries in urban life. These categories are precisely that which the social memory functions to deny. The moments of contradiction in the narratives of the riot all hinge on the neighbourly relationships that define belonging in the mahalle: that in a neighbourly place like Kuzguncuk such a thing couldn't happen, and yet it did; that there was no difference between neighbours of different religions, and yet there was.

One of my interviews, this one with an old Muslim woman, is an especially clear illustration of conflict in her memory of the events. Her memory both conforms to (does not betray) the dominant social memory and yet is also contradictory and sharply individual. ${ }^{59}$ Being Kuzguncuklu ('of Kuzguncuk') means forgetting the events. Yet her 
personal memory bubbles up in our conversation later to challenge the norm. For her, both memories are true.

The 6-7 September Events didn't happen in Kuzguncuk, but I heard about it. They stole ... vandalism ... it happened in [the districts of] Beyoğlu, Eminönü, and Sultanahmet. Our people [Muslims] put them [minorities] out on the street. Oh, the things that happened, the things that happened ... Sounds of tanks were heard here. The noise carried from the other side of the city. On the other side there were gazinos [bars with music] and we heard the music from them across the water. On that night they destroyed the churches... I had three or four Christian friends and I protected them, they stayed in my house. Then after that the Greeks began to leave and go to America, my friends left. My close friends.... during the bad times they stayed with me for fifteen days. (emphasis added)

Much later the teller returns to the events, this time contradicting her statement that the events did not happen in Kuzguncuk, by describing them as a witness. She distinguishes the actors as recent rural Muslim migrants, implying that 'urban' Muslims would never do such a thing.

Turks, Jews, Armenians were not separate in those times. There was no anger at each other. It was when the doctor was killed in Cyprus that it got bad here. Then those who came from Anatolia did it to us. They took their goods, they hit the churches, there were Turkish houses next to the churches. It was the people who came from Anatolia who did it. They broke into the houses, they tied the tanks' wheels and tore fabrics in the houses ... We heard sounds ... they cut the rugs, they ruined things, they took the mattresses of the beds and cut them and threw the wool out of the windows. They broke the glass. One of them sat in front of the jail, wearing several layers of clothes, putting on shoes from a pile of shoes there. What sins were committed here. When they saw the Greeks they turned the other way.

A middle-aged Greek woman also places blame, not on all Muslim Turks, but specifically on rural migrants. She explains that during the 6-7 September events her Muslim friends protected the church and hid their Greek friends under their beds. Then she says, 'But the neighbourliness has disappeared. After the 6-7 September events, places died. In the old days there was civilization. Between Jew, Armenian, and Greek, there was no rudeness. Then when they [rural migrants] began to come it got ruined.' For this woman, the neighbourliness between Muslims and non-Muslims in Kuzguncuk was ruined by rural-urban migration which destroyed true urban culture. The state's role in the riots is never mentioned, and the goodness, the integrity of 'real' or older migrant Muslim Kuzguncuk residents, is preserved with blame on recent rural migrants.

For a Jewish male informant in his early $40 \mathrm{~s}$, recollection of the events is full of tension regarding intracommunity relations in the mahalle. He also blames rural migrants, but blames local 'Turks' as well, for helping them. He heard from his parents that the 6-7 September events were

very dramatic, very sad in Kuzguncuk, and Jews were also affected by these events. But in Kuzguncuk, Greek houses were pillaged and vandalized with stones and it was done by people who came from Anatolia, although some of the Turks bere showed them the way, saying this house is Greek, throw it over there, this house is Jewish, don't throw a stone here. These are sad things but they were done by 
those who came later. In Kuzguncuk, whether Muslim, Greek Armenian, Jewish, there was a good relationship between them, there was a good feeling of brotherhood and sisterhood. (emphasis added)

First the teller acknowledges difference between Muslims and non-Muslims in Kuzguncuk, saying the Turks showed the rioters the way to minority homes, and then he pulls back from this statement to reinforce the goodness of neighbours and say it was really done by recent migrants to Kuzguncuk. He conforms his narrative to the dominant memory, preserving the 'urban' Kuzguncuk as the place of civilized, positive neighbourly relationships and marking the doers of violence as migrant, and therefore non-urban, outsiders.

For all Kuzguncuk people the riots are a painful memory: for most people the memory is too painful or shameful to remember, and they deny the riots ever happened. The narrative moments of tension (the contradiction that claims the riots didn't happen and then witnesses their happening) centre on Kuzguncuk's identity as a place where religion never divided neighbours, where everyone belonged. The riots are a moment when the state employed force to mobilize prejudice based on existing categories of difference. For all non-Muslims, the riots made the boundaries of these categories unforgettably visible, and created fear and insecurity over future claim to safe place in the city. For those remembering, the riots were committed by outsiders, the new immigrants whose culture of non-tolerance reflected their 'non-urban' origins, reinforcing the narrative of Kuzguncuk's (and Istanbul's) cosmopolitanism as the defining feature of its particular urban character. Stories of the riots demonstrate the need to create belonging and collectivity in remembering the mahalle while also revealing the boundaries that fragmented it.

Mahalle space, defined by the category of Kuzguncuklu with boundaries that inscribe insider/outsider and neighbour/foreigner, are produced through the same hegemonic cultural politics that produce the nation as a space. Jane $M$. Jacobs argues that definitions of 'self' and 'other' are 'building blocks for hierarchies of power', a power which is inherently spatial. ${ }^{60}$ The city was an important component of this power, as the city is not only where the self and other met also the 'geographical articulation' of imperial power, the space of 'the "opaque" intersections between representational practices, the built form and a range of other axes of power which determine the precise historical context within which imperialism does and does not hold'. ${ }^{61}$ While Jacobs describes the urban of imperialism, I borrow from her analysis to argue that similarly, the boundaries of exclusion and inclusion in the Turkish nation, defined in terms of 'minority' and 'Turk', were inscribed upon the urban landscape with political and economic policies that transferred minorityowned properties to 'ethnic Turks'. These policies forced or encouraged the emigration of most non-Muslims from Istanbul. Narratives of the mahalle, those which reinforce the dominant memory of multiethnic tolerance, and those which challenge this memory with 'other' stories of violence and fear, betray the constructed nature of the categories 'minority' and 'Turk', exposing the vulnerability, tension and uncertainty embedded in the boundaries which define the nation. 


\section{Conclusions}

\section{Boundaries of nostalgia: the mahalle as the site of history}

Postmodern culture is a wave we ride in the disorganizing and all pervasive economy of late capitalism. Awash in a sea of faces, we look back nostalgically to the shore in a sudden memory of a ground already lost... Now, threatened with a deadening pluralism that makes us all just an other among others, ... nostalgia becomes the very lighthouse waving us back to shore, the one point on the landscape that gives hope of direction. ${ }^{62}$

Interrogating the mahalle landscape leads us to reading the nostalgia at the core of the social memory. Kathleen Stewart's words direct us first to the alienation of the postmodern city. If we are 'all an other among others', none of us belongs to the 'self', to the collectivity-there is no place to signify the belonging of home. If social, cultural, or collective memory is fundamentally dependent on location, place layers this space with meaning: place is the location of memory. Stewart's nostalgia becomes, in the alienating city, 'the one point on the landscape' - or the place - 'that gives hope of direction'. By Christine Boyer's definition, the postmodern urban landscape is characterized by the very employment of material forms that recall a collective memory of the past. ${ }^{63}$ The nostalgia creates this point on the landscape by bringing itself into form in the 'authentic' mahalle. As the landscape of collective memory brings nostalgia to materiality, it performs the illusion of making a past way of life 'real' once again. The mahalle landscape of Kuzguncuk creates the illusion of belonging in place; it creates, in urban space, a collectivity that fills the void of alienation. In its very denial of the condition of being an 'other among others', it signifies cultural mourning for a loss of place in the city.

The nature of Istanbul's contemporary cultural crisis, however, extends beyond a mere postmodern urban malaise. The 'social memory' mahalle of tolerance and multiethnic harmony in place tells us that more is at stake. Why is it important to write into the narrative of the mahalle the characters of Serkiz, the Armenian sweetshop owner, and Ilya, the Greek market gardener, whose names signify cosmopolitanism? And what of the memory of these characters, which, with the authority of a witness, is employed like narrative evidence to prove there truly once was a 'siblinghood' where 'religion never divided us'?

\section{Nostalgia for the minority}

Serkiz and Ilya are remembered in the narrative; old Turkish-Muslim neighbours like Mehmet or Ali are never important enough to mention. Serkiz and Ilya are of note only because they are the 'other', the minority. And the category of minority, argues Bauman, was created by the nation; remembering local minority neighbours in the mahalle as special occurs only because of the larger and invisible category of nation that conditions urban life. The ethnic identity of Serkiz and Ilya was never a 'natural', 
pre-existing essential quality. Their ethnicity exists only as the product of, and in relation to, a national cultural politics. Natter and Jones argue for unpacking the hegemonic nature of the formation of the categories of nation and minority, and ask, 'How are the differences collapsed in the category defined and maintained?" ${ }^{64}$ The mahalle, as the space of the city, is the site of national boundary-making, both in the discourse that creates the mahalle of social memory and, more importantly, as urban territory upon which hegemonic structures of power, through nationalist policies, created and destroyed claims to place for 'Turks' and 'minorities' and shaped the politics of identity enacted in urban space. For Jacobs, 'These struggles produce promiscuous geographies of dwelling in place in which the categories of Self and Other, here and there, past and present, constantly solicit one another'. ${ }^{65}$ The material urban fabric of the mahalle is one such promiscuous geography; it and its reflection, the social memory, are reproduced within and through the nation.

Zygmunt Bauman bridges this analysis of the mahalle as a nostalgic response to the need for community in the postmodern city to ideas of the community as a category of belonging within the nation. He argues that the purpose of national culture is to 'loosen the grip' of local communities on the nation, ${ }^{66}$ to create an overarching category of belonging more powerful than the previous category of the local community. His reads nostalgia for the 'sweetness of belonging' as a response to the failure of the nation to successfully create the overarching imagined community. In order for the nation's imagined community to succeed, ethnic communities must eventually assimilate or perish, which he terms the 'annihilation of difference'. ${ }^{67}$ The mahalle represents the very instability of the 'minority-nation' relationship: the category of nation produced the ethnic minority, and then proceeded to destroy the minority in order to achieve hegemony (to territorialize itself, in the case of Turkey to 'Turkify' the territory). The curious paradox of recalling the presence of minorities in the mahalle through the social memory, while simultaneously employing a language of tolerance to deny the history of antiminority violence, is an 'assimilatory pressure' which 'strip[s] the "others" of their "otherness"; to make them indistinguishable from the rest of the nation's body, to digest them completely and dissolve their idiosyncrasy in the uniform compound of national identity. ${ }^{68}$ Naming Ilya and Serkiz maintains the self-other boundary of minority and nation, even as the tolerance narrative attempts to naturalize the boundary by folding the minorities back into the community, reidentifying them not as a threat or other but as safe, familiar, of 'home'. In this way the minorities are assimilated into the social memory of Istanbul, and the violence that inscribed boundaries of self-other in the nation within the space of the city are denied. The boundaries of the nation have succeeded in the annihilation of difference, enveloping the minorities too as part of the community and no longer 'other'.

However, this telling itself is happening within a Turkish space. It is the TurkishMuslim majority which ascribes value to old Ilya and Serkiz in remembering them by name. In this way the telling also reifies difference, as it comes from a position of power congruent with the dominant, hegemonic culture of the nation. I borrow here from Dipesh Chakrabarty, who describes a tie between value and prejudice in his work on 
Hindu Bengali narratives that recall with nostalgia the harmony between Hindus and Muslims before the violent partition of 1947.

in moments of crisis, not only do our values play a role in producing a sense of home, a sense of community among ourselves and with others ... they can also stop us from hearing what the other might be saying to us at that moment. ... 'Poetically, man dwells' ... true, but within the poetry lies the poison of inescapable prejudice, all the more unrecognizable because it comes disguised as value. ${ }^{69}$

The nostalgia for tolerance and close community relations of the mahalle of collective memory betrays a deep and polarizing difference in identity. Greek and Jewish minorities are beloved, and their homes restored, only after they themselves have abandoned the city and no longer pose a challenge to the space of the nation. They are present in contemporary urban culture today, then, only through their very absence. The nostalgic mahalle of social memory works by deflecting attention from contesting claims to place in the Turkish nation; this is visible in which narratives of the city prevail ('religion never divided us') and which remain unsaid (personal loss of property in taxes, riots, deportation or confiscation).

\section{National boundaries}

The social memory of mahalle life narrates the past with the language of 'we were all siblings' because Turkish nationalism broke apart what was once an integrated mosaic of different identities cohabiting in cosmopolitan daily life. Today, these different identities no longer form a cohesive cosmopolitan mosaic, but exist alongside one another as fragments, categories with rough edges and unacknowledged friction between them that contain the potential of future violence. The memory of mahalle life on the main street in Kuzguncuk produces an imagined cultural space that refers not to the past, but to what is happening now. It has become necessary to remember a tolerant multiculturalism in order to cope with the tensions in contemporary life. Nostalgic memories of the minority neighbours of the past erase tension by making invisible minority claims to place, by denying the social difference that nationalism turned into injustice and dispossession. 'By now, traditions have been so thoroughly "invented" or homogenized, and "history" so absolutely marketed or commodified, misrepresented, or rendered invisible, that any oppositional potential rooted in collective memory has been eclipsed completely. ${ }^{70}$ There is, today, no space for alternative narratives of Kuzguncuk: the collective memory of multicultural harmony has become a Turkish cultural space, existing within the hegemony of the nation.

But have these boundaries really succeeded? The social memory betrays, as well, the very fragility of the boundaries of the Turkish nation and their failure to create a conceptual space of belonging. Urban alienation suggests that the boundaries have not succeeded to create a 'self' with an 'other'. In Turkey today, the boundaries which define the terms of inclusion and exclusion in the nation have come under debate both from inside Turkey and within its international context as a Muslim country petitioning for EU candidacy. These debates are rooted in the foundation of the Turkish Republic 
as a secular, modern nation and yet with boundaries of identity that include only those who are ethnically Turkish and Muslim. Cultural and political tensions in Istanbul, caused by the city's population of overwhelmingly rural origin and the increasing visibility of political Islam, as well as the presence of Kurdish refugees from the southeast of Turkey (a constant reminder of recent and ongoing state violence as well as the existence of ethnic minorities in Turkey), are fuelling cultural debates over 'what nativeness signifies, what sort of everyday comportment... Turkish authenticity requires' ${ }^{71}$ Prime Minister Erdoğan straddles an uneasy line as he seeks support from his Islamist party and majority popular opinion while initiating reforms demanded by the European Union, projecting a simultaneously Turkish and Muslim and yet European Union-member identity for the nation. The boundaries of any nation are continuously re-created in relationship to other nations. How can boundaries encircle the Turkish nation as a space, when the nation requires the internal integrity of a consistent imagined community, and yet must acknowledge demands for ethnic and religious pluralism in a democratic state? The discourse that produces the narrative of the nation reveals its very core to be unstable, and its boundaries to be porous, shifting and vulnerable.

This study of social memory and mahalle life in Kuzguncuk reveals the complexity of issues at stake in narratives of history in Istanbul. The landscape is the material discourse of contesting notions of what constitutes the urban, and who belongs in the nation, mediating the interchange between dominant and minority identities, and between memory and practice in urban life. The place narrative articulates, perhaps, a future vision of the city as a space of belonging and safety in response to the visible intolerance and inequality in Istanbul today. If the state's history of anti-minority violence and territorial dispossession cannot be acknowledged in an open cultural discourse, 'valuing' minorities may be the only way to mourn the demise of the city's characteristic cosmopolitanism. What is certain is that the social memory of Kuzguncuk betrays a cultural moment of insecurity in Istanbul concerning one's claim to place in the city and as a member of the nation.

\section{Acknowledgements}

This article is based on doctoral dissertation research conducted in Istanbul while the author was part of the Department of Geography, University of Texas at Austin. The research was supported by a Fulbright-Hays Fellowship, a University of Texas Population Research Center Mellon Fellowship, the Graduate School of the University of Texas, and the Institute of Turkish Studies. This article was prepared with the support of the University of Kentucky Women in Under-Represented Areas Postdoctoral Fellowship. Thanks to my mentor, Ian Manners. Thanks also to Anna Secor. Many thanks to my three anonymous reviewers for their excellent suggestions. Thanks especially to Rich Schein and the participants of the University of Kentucky Social Theory Working Papers Series. Any remaining faults in the writing or analysis of this material are the responsibility of the author. 


\section{Notes}

${ }^{1}$ In this paper I use the terms 'Muslim' and 'Turk' as they are used by people themselves in Kuzguncuk. In this case, to be Muslim does not necessarily mean daily religious practice. In Turkey, religious identity is acquired at birth and is indicated on state identification cards. Since Atatürk defined Turkey as an ethnically Turkish and Muslim state, until today, the category 'Turk' used in common speech usually refers to someone who is also Muslim, and indeed, the country's population is predominantly Muslim. It is also a secular state, and most of the people I met identify as secular. In my conversations with ethnic minorities and with Turkish Muslims both, the word 'Türk' meant Muslim, just as 'Müsevi' meant Jewish, and 'Rum' meant Greek Orthodox (Greek nationals are called 'Yunanl1'). I raise the issue here to expose the paradox of a revived multiethnic history drawing a Muslim elite to Kuzguncuk, while it does not draw any former Jews or Greeks back to renovate houses and live there, revealing the significance of this popular social memory of cosmopolitan multiculturalism for 'Turks'.

2 D. Mitchell, The lie of the land: migrant workers and the California landscape (Minneapolis, University of Minnesota Press, 1996).

${ }^{3}$ Cosmopolitanism constitutes the social memory of 'the urban' in Istanbul, and is written into the landscapes of formerly minority-dominated areas of Istanbul, in spite of the fact that over 99\% of Istanbul's residents are Muslim. In using this category 'Muslim', I do not mean to obscure either Istanbul's rich diversity or the political inequality and social prejudice which continue to occur because of ethnic and religious difference and place of origin. Kurds and Alevis are the most visible (though certainly not the only) 'minorities' in the city; these categories themselves conceal a range of differences within groups. Istanbul also hosts economic and political migrants from Africa and south-west and central Asia.

${ }^{4} \mathrm{I}$ made this decision in response to methodological issues raised by feminist geographers concerning power and positionality in the production of knowledge. S. Hanson, 'Geography and feminism: worlds in collision?', presidential address, Annals of the Association of American Geographers 82 (1992), pp. 569-86.

${ }^{5}$ Cultural landscape studies view the landscape as fundamental to the processes of social reproduction, a 'material discourse' created by and constitutive of the larger power dynamics that work through it: R. Schein, 'The place of landscape: a conceptual framework for interpreting an American scene', Annals of the Association of American Geographers 87 (1997), pp. 660-80. The landscape thus has a role in reifying or challenging dominant discourses (Mitchell, The lie of the land). Kuzguncuk's landscape positions an identity in relation to nationalist discourse, though it is created by a group of private residents who articulate an aesthetic defining their identities as 'Istanbullu' ('of Istanbul'): see J. Duncan and N. Duncan, 'The aestheticization of the politics of landscape preservation', Annals of the Association of American Geographers 91 (2001), pp. 387-409.

${ }^{6}$ The processes shaping landscapes involve narratives of memory which give a group a cohesive identity within the present. Collectively held social or cultural memory has long been theorized in geographical terms as being located in a particular place: M. Halbwachs, The collective memory (New York, Harper Colophon, 1980); P. Nora, Realms of memory: the construction of the French past, vol. 1 (New York, Columbia University Press, 1998). Memory and the landscape are embedded within one another, as the memory requires a 'display' to give it meaning: S. Hoelscher, 'Making place, making race: performances of whiteness in the Jim Crow south', Annals of the Association of American Geographers 93 (2003), pp. 657-86. In the case of Kuzguncuk, the social memory of the 'urban' and the 'maballe' acquire an authenticity through the landscape, which, in turn, enables this narrative of the past: 
see D. Delyser, 'Authenticity on the ground: engaging the past in a California ghost town', Annals of the Association of American Geographers 89 (1999), pp. 602-32.

7 S. Hoelscher and D. Alderman, 'Memory and place: geographies of a critical relationship', Social and cultural geography 5 (2004), p. 349.

${ }^{8}$ In my interviews, nearly every resident started with the dominant social memory-narrative of multiethnic tolerance, and yet some interviewees later contradicted this narrative.

9 In this respect, notions of the urban in Istanbul resemble those in other urban areas in the former Ottoman empire - see the cases of Damascus, Syria, and Fez, Morocco: C. Salamandra, A new old Damascus: authenticity and distinction in urban Syria (Bloomington, Indiana University Press, 2004); G. Porter, 'Unwitting actors: the preservation of Fez's cultural heritage', Radical bistory review 86 (2003), pp. 123-48.

10 R. Bali, Tarz-ı Hayat'tan Life Style'a: Yeni Seçkinler, Yeni Mekanlar, Yeni Yaşamlar [From style of life to lifestyle: new elites, new places, new lives] (Istanbul, İletişim Yayınlar, 2002), pp. $134-41$.

11 D. Lowenthal, The past is a foreign country (New York, Cambridge University Press, 1985); D. Lowenthal, Possessed by the past: the heritage crusade and the spoils of history (New York, Free Press, 1996).

12 D. Massey, 'Places and their pasts', History workshop journal 39 (1995), pp. 182-92.

13 The Kurds are not economic migrants, but primarily refugees from the war in the south-east of Turkey who form a new underclass with significantly diminished hopes for social and economic integration in the way of homeownership and gainful employment: C. Keyder, 'Globalization and social exclusion in Istanbul', International journal of urban and regional research 29 (2005), pp. 124-34. Recent efforts to resurrect minority history in Istanbul are made possible partly by the recent Kurdish struggle for human rights and civil liberties. These efforts respond also to external pressure from the European Union on Turkey. These demands are not always successful, however, revealing both their urgency and the strength of nationalist imperatives in shaping cultural and political discourse.

14 There is extensive literature on this topic. See e.g. C. Behar, A neighbourbood in Ottoman Istanbul: fruit vendors and civil servants in the Kasap Ilyas maballe (Albany, NY, SUNY Press, 2003); I. Bierman et al., eds, The Ottoman city and its parts: urban structure and social order (New Rochelle, NY, Aristide D. Caratzas, 1991); S. Mardin, 'Religion and secularism in Turkey', in A. Hourani et al., eds, The modern Middle East (Berkeley, University of California Press, 1993), p. 368. As a subject of study, the mahalle has a complicated historiography as part of Orientalist studies of the 'Islamic city', and was considered an integral element of that city type. See I. Lapidus, 'Traditional Muslim cities: structure and change', in L. C. Brown, ed., From madina to metropolis: heritage and change in the Near Eastern city (Princeton, NJ, Darwin Press, 1973); and J. Abu-Lughod, 'The Islamic city: historic myth, Islamic essence and contemporary relevance', International journal of Middle East studies 19 (1987), pp. 155-76.

15 However, the new system also reified separate, group identity: D. Schroeter, 'The changing relationship between the Jews of the Arab Middle East and the Ottoman state in the nineteenth century', in A. Levy, ed., Jews, Turks, Ottomans: a shared bistory, fifteenth through the twentieth century (Syracuse, NY, Syracuse University Press, 2002), pp. 88-107. Furthermore, social difference and prejudices remained: G. Augustinos, The Greeks of Asia Minor: confession, community and ethnicity in the nineteenth century (Kent, $\mathrm{OH}$, Kent State University Press, 1992), p. 38.

16 S. Mardin, 'Religion and secularism in Turkey', in A. Hourani, P. Khoury and M.Wilson, eds, The modern Middle East (Berkeley, University of California Press, 1993), p. 368.

${ }^{17}$ Behar, Neighbourbood, p. 5. 
${ }^{18}$ Ibid. Within millets there were differences in origins and language. Further, ethnic and religious identity was sometimes confused, as in the case of Greek Orthodox communities that spoke Turkish, or Greek Jews speaking Ladino: R. Clogg, 'A millet within a millet: the Karamanlides', in D. Gondicas and C. Issawi, eds, Ottoman Greeks in the age of nationalism: politics, economy and society in the nineteenth century (Princeton, NJ, Darwin Press, 1999), p. 117.

19 Behar, Neigbbourbood, p. 4.

20 I. Tamdoğan-Abel, 'Osmanlı Döneminden Günümüz Türkiye'sine 'Bizim Mahalle" [Our mahalle from Ottoman times to today's Turkey], Istanbul Dergisi 40 (2002), pp. 66-70.

${ }^{21}$ S. Zubaida, 'Introduction', in R. Meijer, ed., Cosmopolitanism, identity and autbenticity in the Middle East (Richmond, Surrey, Curzon Press, 1999), p. 1 (emphasis added).

${ }^{22}$ Z. Bauman, Culture as praxis (London, Sage, 1999), p. xxx.

${ }^{23}$ B. Anderson, Imagined communities: reflections on the origin and spread of nationalism (New York, Verso, 1991).

${ }^{24}$ The word azinlik was not used to refer to Kurds or other groups considered minorities in Turkey today. The identity of Kurds as an ethnic minority was completely denied by a nationalist narrative that described them as actually 'Turkish', qualifying their difference by calling them 'mountain Turks'. It was during the 1990s, during an opening of discussion regarding minorities in Turkey (brought about in part by the work of Kurdish activists and others after the war between the Turkish army and the Kurdistan Workers' Party in the southeast), that Kurds and other groups began to claim a minority status and thus expose their collective oppression by the state.

25 The Young Turk era, between 1908 and 1918, was a time of continuing fragmentation of the empire. The Paris peace conference proposed to cede Balkan and Arab provinces of the empire to European control, and place areas occupied by Turkish populations in Anatolia under foreign or minority control. Izmir was captured by Greek armies in 1922.

26 Atatürk was inspired by Mehmet Ziya Gökalp, who differentiated between 'culture' and 'civilization', separating the values of a community from the system of knowledge that governs it. Gökalp argued that the Turkish nation had its own strong culture, but that it had been submerged in an Islamic/Arab and partly Byzantine civilization: E. Zürcher, Turkey: a modern bistory (New York, Tauris, 1995), p. 136.

27 E.g. H. Şahin, 'Türkiyeli, Türk, Alt-Kimlik, Üst-Kimlik' [To be of Turkey, to be a Turk: inner identity, external identity], Radikal online, 22 Oct. 2004.

28 Intermarriage, for all communities in Kuzguncuk, carried a social stigma in the past and it does so today. I heard about several cases of intermarriage in Kuzguncuk and I was also told that it doesn't happen. Intermarriage is an important topic but is beyond the scope of this paper.

29 See e.g. R. Bali, Bir Türkleştirme serüveni 1923-1945 [An adventure in Turkification, 19231945] (Istanbul, İletişim Yayınları, 1999); A. Aktar, Varlik vergisi ve Türkleştirme politikalar [The property tax and Turkification politics] (Istanbul, Iletişim Yayinları, 2000).

30 Turkish census data.

31 In spite of striking temporal and geographical differences, the close social ties of Istanbul mahalles resemble those in other parts of the Middle East, such as in the darb of Morocco; D. Eickelman 'Is there an Islamic city? The making of a quarter in a Moroccan town', International journal of Middle East studies 5 (1974), pp. 274-94; and the murabba' in Cairo: F. Ghannam, Remaking the modern: space, relocation and the politics of identity in a global Cairo (Berkeley, University of California Press, 2002).

32 Pierre Mayol and Michel de Certeau's study of a Paris neighbourhood draws on Henri LeFebvre's theories regarding the production of urban space to define the neighbourhood as 
an intermediary linking space between the public and the private, created through specific cultural practices that maintain relationships of neighbouring: M. de Certeau, Practice of everyday life, vol. 2: Living and cooking (Minneapolis, University of Minnesota Press, 1998); H. Lefebvre, The production of space (Cambridge, Blackwell, 1991). Similarly, the mahalle is a product of cultural practices that inscribe the space with boundaries of inclusion and exclusion, familiarity and foreignness, neighbour and foreigner.

33 M. Bonine, Population, poverty and politics in Middle East cities (Gainesville, Florida University Press, 1997); and C. Keyder, Istanbul between the global and the local (New York, Rowman \& Littlefield, 1999).

${ }^{34}$ Y. Aksoy and M. C. Yalçintan, 'Kutsal topraklara varmadan önceki son durak: Kuzguncuk', [the last stop before reaching the Holy Land], Kent Gündemi 1 (1997), p. 38; see also E. Bayindir, 'Ve Zaman Yenildi' [Time is beaten], Cumburiyet, magazine section, 858, 1 Sept. (2002), pp. 5-7.

35 S. F. Abasiyanik, Maballe Kabvesi (Istanbul, Yapi Kredi Yayınları, 2002).

36 The Turkish word kardeş is not gendered, and means both 'brother' and 'sister'.

37 See the discussion of political Islam in Kuzguncuk in C. Houston, Islam, Kurds, and the Turkish nation state (New York, Berg, 2001).

38 C. Bektaş, Hoşgörïnün öteki adl: Kuzguncuk [The other name for tolerance: Kuzguncuk] (Istanbul, Tasarım Yayın Grubu, 1996); C. Bektaş, 'Kuzguncuk', Istanbul Dergisi 4 (1993), pp. 105-15.

39 Bektaş, Tolerance, p. 34.

${ }^{40} \mathrm{H}$. Tanriöver, 'Türk televizyon dizilerinde aile, mahalle ve cemaat yaşami' [Family, neighbourhood, and community life in Turkish television serials], Istanbul Dergisi 40 (2002), pp. 93-6.

41 The arrival of a wealthier class into this neighbourhood caused an increase in property values: H. Bayindir, 'En Popüler İstanbul Köyü' [The most popular Istanbul village], Milliyet (Istanbul) 3 (18 May 2001), real estate section, p. 3. Historic renovation in Kuzguncuk follows some of the social and economic patterns identified in North American and European literature on gentrification: see C. N. Uzun, Gentrification in Istanbul: A diagnostic study. (Utrecht, University of Utrecht, 2001); and C. N. Uzun, 'The impact of urban renewal and gentrification on urban fabric: three cases in Turkey', Tijdschrift voor Economische en Sociale Geografie 94 (2003), pp. 363-75. The political economy of gentrification, and the social, political, gendered and cultural identities of those who participate in gentrification and those who are adversely affected by it, are all significant elements of this transformation but are beyond the scope of this paper.

${ }^{42}$ See e.g. Aksoy and Yalçintan, 'Holy Land'; and D. Çakil and M. Duğen, 'Istanbul'da küçük bir Paris' [A little Paris in Istanbul], Akademist 1 (2002), pp. 24-9.

43 Long-term migrant, Muslim residents told me about social and economic disruption in their neighbourhood caused by the gentrification.

${ }^{44}$ Mitchell, The lie of the Land, p. 6.

${ }^{4}$ B. Özden, 'Hrisokeramas'tan Kuzguncuk'a' [From Hrisokeramas to Kuzguncuk], Radikal (Istanbul, 9 July 2002), p. 13.

46 www.kuzguncuk.org last accessed 2 May 2002.

47 Ibid.

${ }^{48}$ For example, $40 \%$ of the properties abandoned in the 1964 deportation of Greeks from Istanbul were listed as 'abandoned' and eventually claimed by the Turkish state: H. Demir and R. Akar, İstanbul'un son sürgünleri [Istanbul's last exiles] (Istanbul, Belge Yayınları, 1999), p. 190. 
49 A. Alexandris, The Greek minority of Istanbul and Greek-Turkish relations of 1918-1974 (Athens, Center for Asia Minor Studies, 1983).

50 T. Bahcheli, Greek-Turkish relations since 1955 (Boulder, CO, Westview Press, 1990), p. 174.

51 Ibid.

52 I have changed the names of my informants to protect their privacy.

53 Censorship of the press, closure of archives and mutual consent within minority communities not to expose themselves or dredge up painful memories work together to make research on the loss of minority properties prohibitively difficult.

54 Mitchell, The lie of the land, p. 6.

55 F. Ökte, The tragedy of the Turkish capital tax (Wolfboro, NH, Croom Helm, 1987); Bali, Bir Türklestirme serïveni; Aktar, Varlık vergisi.

56 Ibid. p. 204.

57 Ibid. p. 206.

58 Bahcheli, Greek-Turkish relations, p. 173.

59 Yael Navaro-Yashin argues that the remembering and forgetting of Turkish state scandals is necessary to the survival of the state-society relationship. For Navaro-Yashin, the state and society in Turkey are inseparable. She uses the word 'cynicism' (with reference to the work of Slavoj Zizek) to explain the process of complying with the state, of adopting an apathy that permits the upkeeping of everyday practices, as if one doesn't know the state's fallacies and failures, although its failures are known to all. This explains the rapid explosion and subsequent disappearance of news about scandalous events regarding the state in the media and in popular consciousness: Y. Navaro-Yashin, Faces of the state: secularism and public life in Turkey (Princeton, NJ, Princeton University Press, 2003), pp. 159-87.

60 J. Jacobs, Edge of empire: postcolonialism and the city (New York, Routledge, 2002), p. 4.

61 Ibid. p. 10.

62 K. Stewart, 'Nostalgia: a polemic', Cultural antbropology 3 (1998), pp. 227-41.

${ }^{63}$ M. C. Boyer, The city of collective memory: its bistorical imagery and architectural entertainments (Cambridge, MA, MIT Press, 1996).

${ }^{64}$ W. Natter and J. P. Jones III, 'Identity, space, and other uncertainties', in G. Benko and U. Strohmayer, eds, Space and social theory: interpreting modernity and postmodernity (Cambridge, MA, Blackwell, 1997), pp. 141-61.

65 Jacobs, Empire, p. 5.

66 Bauman, Culture as praxis, p. xxxvi.

67 Z. Bauman, Community: seeking safety in an insecure world (Malden, MA, Blackwell Press, 2001), p. 93.

68 Ibid. p. 93.

69 D. Chakrabarty, 'Memories of displacement: the poetry and prejudice of dwelling', in D. Chakrabarty, ed., Habitations of modernity: essays in the wake of subaltern studies (Chicago, Chicago University Press, 2002), p. 137.

${ }^{70}$ Boyer, City of collective memory, p. 5.

${ }^{71}$ Navaro-Yashin, Faces of the state, p. 21. 